\title{
Ryegrass endophyte and cattle growth in Northland
}

\author{
H.S. EASTON ${ }^{1}$ and J.N. COUCHMAN ${ }^{2}$ \\ ${ }^{1}$ AgResearch, Grasslands Research Centre, Private Bag 11008, Palmerston North \\ ${ }^{2}$ AgResearch, Kerikeri Research Centre, P.O. Box 23, Kerikeri \\ ${ }^{1}$ eastons@agresearch.cri.nz
}

\begin{abstract}
Perennial ryegrass pastures infected with or free of the endophyte (Neotyphodium lolii) were compared for growth and health of young grazing cattle. Heat stress, indicated by excessive salivation, was observed on several occasions among cattle grazing endophyte-infected ryegrass, but there were no differences between groups in body temperature. Liveweight gains were generally slow and inconsistent. During one period of rapid liveweight gain in March-April 1997, heifers grazing endophytefree pastures gained $7 \mathrm{~kg}$ more than heifers grazing infected pasture. Taking data from three four-week grazing periods in summer and autumn, liveweight change of cattle grazing endophyte-free pastures showed a consistent advantage over cattle grazing endophyte-infected ryegrass. Significant differences in serum prolactin were recorded on two occasions, and on one day in February 1998 weaner bulls grazing infected ryegrass were breathing significantly faster than their counterparts on endophyte-free pasture. These results can be compared with previous reports that endophyte status of ryegrass pastures has little effect on grazing cattle, and contrast with the published literature for tall fescue.
\end{abstract}

Keywords: liveweight gain, Neotyphodium lolii, perennial ryegrass, ryegrass endophyte

\section{Introduction}

Effects of unselected, wild-type endophyte (Neotyphodium lolii) on sheep have been very well documented (Fletcher et al. 1990; Fletcher et al. 1999; Watson et al. 1999). Ryegrass staggers, poor growth of hoggets and lambs (pre- and post-weaning), elevated body temperatures and respiration rates, and depressed serum prolactin concentrations have all been recorded.

The endophyte-derived factor causing ryegrass staggers is lolitrem B, an indole diterpenoid (Gallagher et al. 1981). Ergovaline, an ergopeptine responsible for toxicosis caused by the related grass tall fescue (Festuca arundinacea) infected with a similar endophyte (N. coenophialum) (Yates et al. 1985), was also shown to be present in significant amounts in infected perennial ryegrass (Rowan \& Shaw 1987). Typical herbage concentrations of ergovaline in New Zealand ryegrass pastures are between 0.3 and $1 \mathrm{ppm}$ (Easton et al. 1996), and this is about $60 \%$ of concentrations frequent in USA tall fescue pastures (Garner et al. 1993; Lyons et al. 1986). Many USA publications cite concentrations determined after the removal of ergovalinine, a pharmacologically less active isomer, whereas New Zealand data are for the sum of the two isomers (see Lane 1999). Concentrations in roadside tall fescue in New Zealand are very much higher (G.A. Lane pers. comm.).

Cattle grazing endophyte-infected tall fescue in south-east USA typically show poor weight gain, poor growth of suckling calves, elevated body temperatures, evident heat stress (excessive salivation, protruding tongue) and depressed serum prolactin levels (Hoveland 1993; Schmidt \& Osborn 1993; Stuedemann \& Hoveland 1988). A summary of 12 trials in 10 states of USA showed mean average daily gain (ADG) of steers grazing endophyte-infected tall fescue of $420 \mathrm{~g} /$ day compared with $740 \mathrm{~g} /$ day for those grazing endophytefree pastures. Five cow/calf trials showed mean ADG of cows on infected pastures as $20 \mathrm{~g} /$ day $(250 \mathrm{~g} /$ day on endophyte-free), only $59 \%$ pregnancy ( $87 \%$ ) and ADG of calves $700 \mathrm{~g} /$ day (890 g/day) (Schmidt \& Osborn 1993). A combined analysis of 12 trials in 7 states ( 37 location-years) showed mean spring ADG of steers as $630 \mathrm{~g} /$ day on infected pastures, $760 \mathrm{~g} /$ day on intermediate pastures (20-35\% infected) and $840 \mathrm{~g} /$ day on endophyte-free pastures (Thompson et al. 1993). Respective summer ADG's (based on 5 trials and 17 location-years) were $374 \mathrm{~g} /$ day, $525 \mathrm{~g} /$ day and $542 \mathrm{~g} /$ day.

Heat stress has from time to time been observed in cattle in Northland and Bay of Plenty, and been ascribed to the presence of wild "roadside" tall fescue (Brookbanks et al. 1985; Sutherland 1984). These symptoms and their occurrence, the pasture type and ergovaline concentration in the pasture, are all consistent with heat stress being caused in New Zealand by ryegrass endophyte (Easton et al. 1996).

There has, however, been very little research on effects of ryegrass endophyte on cattle in New Zealand. A two-year trial in Manawatu found that while ryegrass 
staggers was recorded in both seasons, yearling or weaner bulls grazing endophyte-infected ryegrass over a prolonged season gained weight as well as those on endophyte-free ryegrass and showed no other adverse effects (Cosgrove et al. 1996). In the second season, weaner bulls rotationally grazing endophyte-free ryegrass showed a $28 \%$ higher daily herbage intake than a control group on infected ryegrass, but this was not reflected in liveweight gain. These results were at variance with extensive results from USA, showing severe effects of tall fescue endophyte infection on liveweight gain and welfare of cattle. Possible explanations for these differences are lower concentrations of ergovaline in ryegrass than tall fescue herbage, more stressful temperatures usually prevailing in the fescuegrazing areas of USA or the existence uniquely in tall fescue of other unknown factors exacerbating the effects of ergovaline.

The Dairying Research Corporation has conducted short term experiments with milking cows, and measured no effects or only very inconsistent effects of endophyte (Clark et al. 1996; McCallum \& Thomson 1994; Thom et al. 1994; Thom et al. 1999). The trials were of a duration which has regularly been used to determine effects of feed quality or feed intake, and it had been expected that any important effects would have been evident. Again, these results are at variance with results of a trial in South Australia (Valentine et al. 1993), in which a significant depression of milk yield due to endophyte was documented. The protocol for the South Australian trial was similar to that of the DRC trials.

In this paper we report on a trial conducted to determine effects of endophyte on cattle in the warmer environment of northern New Zealand.

\section{Materials and methods}

\section{Trial location}

The trial was established on a farm property near Kaeo, Northland, New Zealand. An area of 8 ha was available, divided into eight 1 ha paddocks with a race down the middle. The area was in old ryegrass-based pasture, with significant annual $\mathrm{C}_{4}$ grass presence.

\section{Pasture establishment}

On 2 May 1996, after a regime of strict pasture control through the preceding spring and summer which prevented any seed development, and destruction of the old sward with glyphosate and dicamba (20 April 1996), two paddocks were sown to each of the following:

- Grasslands Nui perennial ryegrass, free of endophyte

- G. Nui perennial ryegrass, infected with wild-type endophyte
- G. Nui ryegrass infected with endophyte and Grasslands Kopu white clover

Fertiliser was applied as indicated by soil tests. Olsen $P$ tests ranged across the trial site from 19 to 31 in June 96, and from 14 to 28 in September 97. The new pastures established well, and were grazed as required through the winter and spring to encourage sward development. Urea was applied in June $96(50 \mathrm{~kg} / \mathrm{ha})$ and after each grazing round $(30 \mathrm{~kg} / \mathrm{ha})$ in spring and autumn.

In October 1996, single tillers were taken from 30 points across each paddock to determine endophyte infection levels of the new swards. Pastures were regularly treated (every two months, but sometimes delayed to fit grazing schedules) with $2 \mathrm{~kg} / \mathrm{ha}$ isazophos (Miral $10 \mathrm{G}^{\mathrm{TM}}$ ) insecticide to protect the endophytefree swards from insect attack. This insecticide has a 21-day withholding period, so its use imposed constraints on grazing management.

\section{Experimental grazing sequences}

On 4 November 1996, yearling heifers were weighed unfasted, sampled for blood (caudal vein) and assigned to paddocks to achieve a similar paddock mean and variance for liveweight. Five or six animals were initially assigned per paddock.

Paddocks were divided into 5 breaks, and heifers were shifted every two days to complete a grazing rotation in 10 days. Pasture on offer and residual after grazing were measured by a rising plate meter, calibrated by quadrat cuts, at each shift. Heifer numbers were adjusted to achieve similar pasture on offer per head for each paddock.

Heifers were yarded on 28 November, for blood sampling and recording of vaginal temperatures, and were weighed off the trial on 4 December. Blood samples were submitted to an AgResearch laboratory at Ruakura for determination of serum prolactin concentrations. At all times, cattle were weighed unfasted.

A similar grazing sequence was completed from 13 January to 10 February 1997, with ten or eleven yearling heifers per paddock. Rectal temperatures were recorded at these two dates and on 3 February, when liveweight was also recorded. Blood samples were taken on 15 January and 10 February. Pasture samples were cut to ground level on 28 January and 10 February, and a second set of samples plucked to grazing height (5-7 $\mathrm{cm}$ ) on 28 January, and these samples were submitted to the AgResearch laboratory at Palmerston North for endophyte alkaloid analyses.

A third grazing sequence was undertaken from 10 March to 10 April 1997, with six to eight yearling heifers per paddock. Liveweights and rectal temperatures 
were recorded at the beginning and the end of the trial, and on 7 April. Liveweights were also recorded on 27 March. On three warm days, 3-5 undisturbed animals in each mob were closely observed in the field and their respiration rates (as indicated by flank movement) were recorded. Blood samples were taken on 10 April and submitted for determination of serum prolactin concentrations.

Weaner bulls were assigned to the trial in a similar way, five or six per paddock, from 8 January to 4 February 1998. Liveweights were recorded at the beginning and end of the period, and on 21 January, and rectal temperatures were recorded on 21 January and 30 January.

For all grazing sequences, animal number in each mob was adjusted to achieve similar herbage allowances.

Analysis of variance was applied to data for body temperature, respiration rate, serum prolactin concentrations and liveweight change after pooling animals in all mobs for each treatment.

\section{Results}

\section{Ambient conditions}

Ambient temperatures at the trial site for the 1996-97 season, recorded in the shade $2.5 \mathrm{~m}$ above the ground, are shown in Figure 1. Maximum temperatures seldom rose above $30^{\circ} \mathrm{C}$. Temperatures were lower for the spring and autumn grazing sequences than in January-February. However, the minimum and mean temperatures for most of the summer grazing sequence were lower than those in late December and late February.

\section{Pastures}

From paddocks sown to infected ryegrass seed, $91 \%$ of 120 tillers sampled in October 1996 were infected with endophyte, while from paddocks sown to endophytefree ryegrass, none of 60 tillers were infected. Samples taken in January and February 1997 indicated no ergovaline $(0.1 \mathrm{ppm}$ in 1 sample, not detected in 5 others) in the pastures sown to endophyte-free ryegrass, and $0.4-0.8 \mathrm{ppm}$ in the 12 samples of pastures sown with endophyte-infected ryegrass seed.

Botanical composition analysis indicated very high ryegrass proportions early in the season (over $90 \%$ of live leaf in January 1997) with negligible clover even in the "clover" treatment. By 10 March 1997, ryegrass $\%$ had fallen to $60 \%$, with other grasses (annual Setaria viridis and other $\mathrm{C}_{4}$,) making up 30\%. However, by 27 March 1997, C 4 grass growth had slowed and ryegrass improved, so that ryegrass again accounted for $90 \%$ of green leaf, with no differences in botanical composition between the treatments. Clover was not a significant presence (traces only) in any paddock. Therefore, data

Figure 1 Daily ambient temperatures at the trial site through summer 1996-1997.

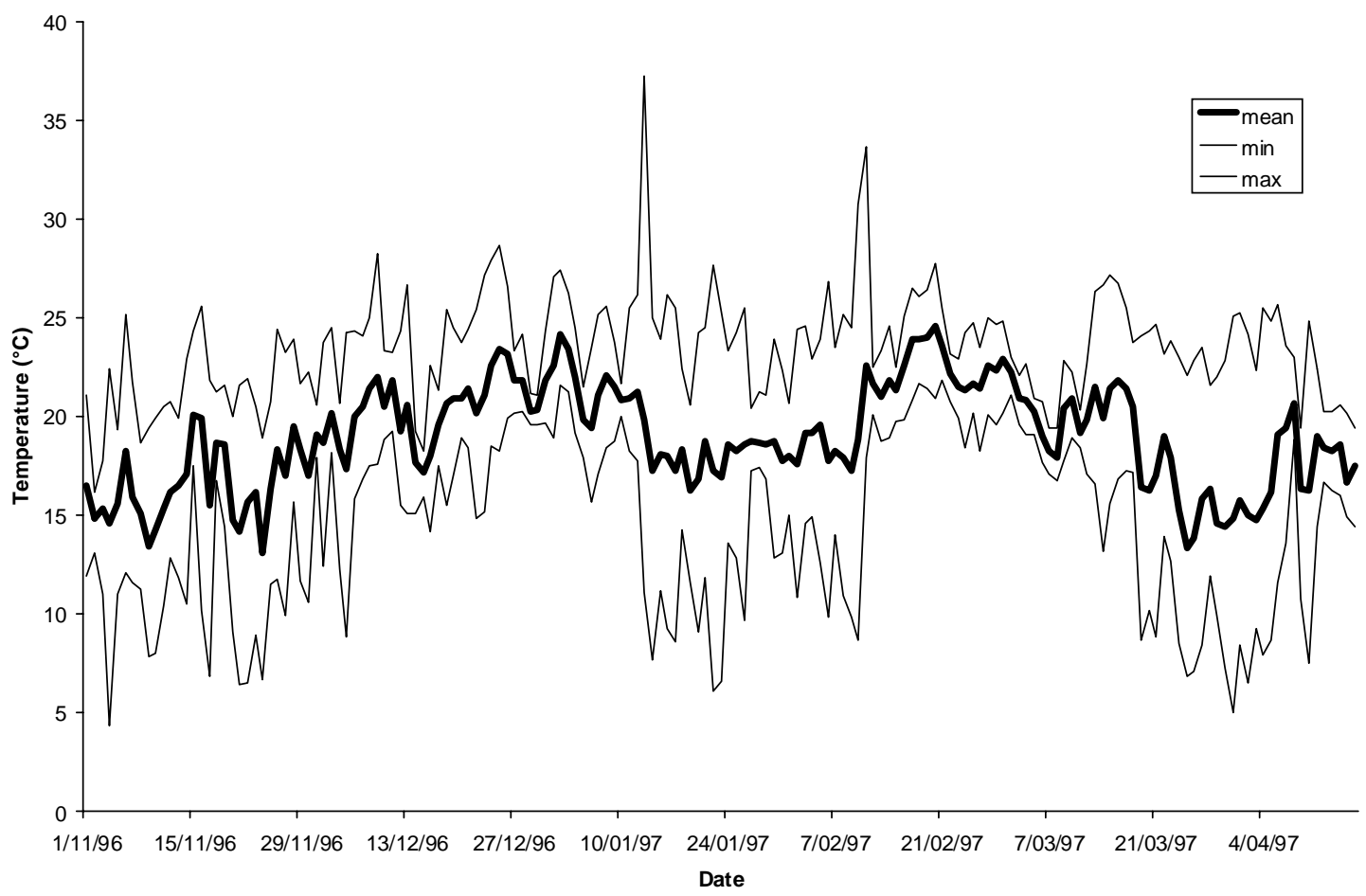


from the clover treatment were included with those of the endophyte-infected treatment.

\section{Feed on offer}

Feed on offer, and estimated daily intake per animal, for the three grazing sequences of the 1996-97 season are given in Table 1. Feed on offer declined as each sequence proceeded. This did not appear to reduce the estimated daily intake (certainly it did not do so for the autumn sequence), although mean daily intake was very low for the second of four rotations in the second sequence (not shown).

\section{Livestock health}

Ryegrass staggers was observed in a few animals grazing endophyte-infected ryegrass in summer and in autumn 1997. On 10 February 1997, heifers in three mobs grazing endophyte-infected ryegrass (5 of 10 in one mob, 7 of 11 in another and 2 of 10 in the third) were recorded as suffering ryegrass staggers. No animals in the fourth mob grazing infected ryegrass, or in the two mobs grazing endophyte-free ryegrass were observed to be suffering. On the same occasion, heat stress, indicated by salivation, was observed for about half the heifers in two mobs grazing infected ryegrass. Salivating animals were observed on several other occasions in summer and autumn 1997 and summer 1998.

At no time were any mean differences in vaginal or rectal temperatures recorded between endophyte treatments. There were differences between animals within a mob (consistent between recording dates), and temperatures increased appreciably and rapidly when animals were held in a crush.

Respiration rates recorded in the summer and autumn of 1997 showed no differences between treatments. On one occasion in summer 1998 (midafternoon, 2 February, temperature $29^{\circ} \mathrm{C}$ ), weaner bulls grazing endophyte-free ryegrass were recorded as breathing 65 times per minute, compared with 84 for those grazing infected ryegrass (means of 6 and 16 animals respectively, $\mathrm{P}=0.01$ ). In summer 1997 and on other occasions in summer 1998, there were no differences between treatment means.

\section{Liveweight gain}

Liveweight comparisons are given in Table 2. Cattle gained weight significantly faster $(\mathrm{P}=0.01)$ on endophyte-free ryegrass in autumn 1997. In summer 1997 and summer 1998, there were small advantages to the endophyte-free treatment. These were not statistically significant in themselves, but the trend over the three summer-autumn grazing periods was significant $(\mathrm{P}=0.03)$. Assuming changes in gut fill did not affect the weights (see Discussion), mean liveweight gain was $28 \mathrm{~kg}$ per head over the first 17 days in the autumn 1997 grazing sequence, and then the animals lost weight in the last 14 days. There were no treatment differences in weight gain in spring 1996.

\section{Serum prolactin concentration}

Mean serum prolactin concentrations were $22 \mathrm{ng} / \mathrm{ml}$ on 4 November 1996, when the first grazing sequence began, and $59 \mathrm{ng} / \mathrm{ml}$ on 28 November. On that day (warm, but not above $25^{\circ} \mathrm{C}$, see Figure 1), heifers grazing endophyte-free ryegrass had mean serum prolactin concentration of $86 \mathrm{ng} / \mathrm{ml}$, compared with 46 for those grazing endophyte-infected ryegrass $(\mathrm{P}=0.01)$.

Mean serum prolactin concentrations were $92 \mathrm{ng} /$ $\mathrm{ml}$ on 15 January 1997, two days after a grazing sequence began, and $22 \mathrm{ng} / \mathrm{ml}$ for the same animals on 11 February. There was no correlation between values for the same individuals on the two dates. On the later date, four animals (one of 15 on endophyte-free, three of 39 on endophyte-infected) had outlier values above 100 $\mathrm{ng} / \mathrm{ml}$. When these were omitted from the analysis, animals grazing endophyte-free ryegrass had a higher mean concentration $(\mathrm{P}<0.001)$ of serum prolactin $(31$ $\mathrm{ng} / \mathrm{ml})$ than those grazing infected ryegrass $(19 \mathrm{ng} / \mathrm{ml})$.

There were no differences in prolactin concentrations in samples taken on 11 April 1997. Mean prolactin concentration for all animals in the trial at this date was $7 \mathrm{ng} / \mathrm{ml}$. 


\section{Discussion}

Endophyte-free pastures were successfully established for this trial, using a protocol of strict grazing control to ensure no seed set in the preceding season, and use of herbicide to kill the old sward. The sward was free of endophyte, assessed microscopically after the first winter and by assaying endophyte-produced alkaloids during the later grazing periods. However, use of a similar protocol in the following year to establish pastures of ryegrass infected with selected endophyte was not successful, with those swards being severely contaminated with volunteer ryegrass (data for these swards are not presented in this paper). It is not clear what factors led to this difference in outcome. The mixed experience underlines the care that is required for successful establishment of swards with special character. The endophyte-free pastures proved vulnerable to insect pressure, and were lost in their second year, in spite of intensive use of insecticide. Insecticide involves constraints on grazing management imposed by withholding periods before grazing. Insecticide application was delayed at crucial points in early summer 1998, to enable continued grazing, and the endophyte-free swards were lost. Some livestock farmers have established endophyte-free swards, but they do run the risk of sudden pasture death.

The ergovaline concentrations measured in the herbage of endophyte-infected swards were of the same order as those reported previously for samples collected on farms in Northland and elsewhere (Easton et al. 1996).

Generally rates of liveweight gain were not high, achieving a $\mathrm{kg}$ or more per day for only short periods. For a two-week period in autumn 1997, yearling heifers grazing endophyte-free ryegrass gained more weight than heifers grazing infected ryegrass. In the following two weeks, there were no differences between treatments. For the three summer and autumn grazing sequences taken together, cattle gained weight faster on endophytefree pasture than on infected pasture.

Cattle were weighed directly off their pasture, without fasting. Before each trial period, animals grazed other pastures on the same farm, but these may well have had different proportions of tropical grasses and other species in the sward than the trial area. Therefore it is likely that the weight of the gut fill was not the same at the beginning of a trial period as at the end. The calculated liveweight changes are thus not a correct estimate of liveweight gain. However, comparisons between treatments within the trial remain valid.

Although herbage intake did not appear to decline through the experimental periods, the declining herbage on offer probably meant that herbage consumed included increasing proportions of leaf sheath, stem and dead material, and declining proportions of live leaf blade, so that forage quality declined. The greatest mean rates of liveweight gain, and the only indications of enhanced gains from endophyte-free ryegrass, occurred when pasture quality was highest.

While appreciable differences were observed in one period, and while there was a consistent trend in the summer-autumn seasons, the modest LWG response to endophyte is not inconsistent with other New Zealand experience (Cosgrove et al. 1996). Certainly, this trial did not reveal responses to pasture endophyte status of the order consistently recorded on tall fescue pasture in USA (Thompson et al. 1993).

Endophyte in pasture affected serum prolactin concentrations for two sampling dates, and was recorded as affecting respiration rates on one occasion. Body temperatures were never shown to be affected. Serum prolactin response is regarded as a very consistent indicator of exposure to ergovaline (Thompson \& Stuedemann 1993). The animals had been on the treatments only two days when sampled for prolactin on 15 January 1997, and in April 1997 the mean prolactin levels were very low. Treatment differences are typically observed when ergovaline inhibits a rise in serum prolactin which would normally be a response to rising ambient temperature. Stemmy non-leafy pasture, probably the case in the later rotations of a grazing sequence, would not lead to high basal prolactin levels.

Cattle do not pant as a normal response to warm conditions as sheep do, so it would not be expected that respiration rate of cattle would respond to endophyte as consistently as has been recorded for sheep (Fletcher $e t$ al. 1990; Fletcher et al. 1999). However, on one warm day mean differences in respiration rate were recorded. Yearling bulls exposed to endophyte toxins were breathing on average $35 \%$ faster.

Animals with evident distress (protruding tongue, severe salivation) were observed from time to time on infected pastures, and animals salivating were regularly observed on infected pastures on warm days in JanuaryFebruary 1997, March-April 1997 and in JanuaryFebruary 1998. The suggestion that episodes of heat stress ascribed to volunteer tall fescue could be caused by endophyte-infected ryegrass (Easton et al. 1996) have proved to be well-founded.

\section{ACKNOWLEDGEMENTS}

This work was funded by Meat New Zealand. A grant was received from the Hinerangi Trust. Our thanks are due to Mr D. Lane for hosting the trial and for his personal involvement with it; and to Mr H. Harris, Kaitaia for his sustained interest, support and veterinary expertise. 


\section{REFERENCES}

Brookbanks, E.O.; Bell, K.C.; Fraser, D.; Kearns, M.P.; Sutherland, R.J. 1985. Hyperthermia in cattle associated with tall fescue (Festuca arundinacea). New Zealand Veterinary Journal 33: 57-58.

Clark, D.A.; Thom, E.R.; Waugh, C.D. 1996. Milk production from pastures and pasture silage with different levels of endophyte infection. Proceedings of the New Zealand Society of Animal Production 56: 292-296.

Cosgrove, G.P.; Anderson, C.B.; Berquist, T.R.N. 1996. Fungal endophyte effects on intake, health and liveweight gain of grazing cattle. Proceedings of the New Zealand Grassland Association 57: 43-48.

Easton, H.S.; Lane, G.A.; Tapper, B.A.; Keogh, R.G.; Cooper, B.M.; Blackwell, M.; Anderson, M.; Fletcher, L.R. 1996. Ryegrass endophyte-related heat stress in cattle. Proceedings of the New Zealand Grassland Association 57: 37-41.

Fletcher, L.R.; Hoglund, J.H.; Sutherland, B.L. 1990. The impact of Acremonium endophytes in New Zealand, past, present and future. Proceedings of the New Zealand Grassland Association 52: $227-$ 235.

Fletcher, L.R.; Sutherland, B.L.; Fletcher, C.G. 1999. The impact of endophyte on the health and productivity of sheep grazing ryegrass-based pastures. Ryegrass endophyte: an essential New Zealand Symbiosis. Grassland Research and Practice Series No. 7: 11-17.

Gallagher, R.T.; White, E.P.; Mortimer, P.H. 1981. Ryegrass staggers: Isolation of potent neurotoxins lolitrem A and lolitrem B from staggers producing pastures. New Zealand Veterinary Journal 29: 189190.

Garner, G.B.; Rottinghaus, G.E.; Cornell, C.N.; Testereci, H. 1993. Chemistry of compounds associated with endophyte/grass interaction: ergovalineand ergopeptine-related alkaloids. Agriculture, Ecosystems and Environment 44: 65-80.

Hoveland, C.S. 1993. Importance and economic significance of the Acremonium endophytes to performance of animals and grass plant. Agriculture, Ecosystems and Environment 44: 3-12.

Lane, G.A. 1999. Chemistry of endophytes: patterns and diversity. Ryegrass endophyte: an essential New Zealand Symbiosis. Grassland Research and Practice Series No. 7: 85-94.

Lyons, P.C.; Plattner, R.D.; Bacon, C.W. 1986. Occurrence of peptide and clavine ergot alkaloids in tall fescue grass. Science, USA 232: 487-489.

McCallum, D.A.; Thomson, N.A. 1994. The effect of different perennial ryegrass cultivars on dairy animal performance. Proceedings of the New Zealand Society of Animal Production 54: 87-90.

Rowan, D.D.; Shaw, G.J. 1987. Detection of ergopeptine alkaloids in endophyte-infected perennial ryegrass by tandem mass spectrometry. New Zealand Veterinary Journal 35: 197-198.

Schmidt, S.P.; Osborn, T.G. 1993. Effects of endophyteinfected tall fescue on animal performance. Agriculture, Ecosystems \& Environment 44: 233262.

Stuedemann, J.A.; Hoveland, C.S. 1988. Fescue endophyte: history and impact on animal agriculture. Journal of Production Agriculture 1: 39-44.

Sutherland, R.J. 1984. Ideopathic bovine hyperthermia. Surveillance 11: 16-17.

Thom, E.R.; Clark, D.A.; Prestidge, R.A.; Clarkson, F.H.; Waugh, C.D. 1994. Ryegrass endophyte, cow health and milk solids production for the 1993/94 season. Proceedings of the New Zealand Grassland Association 56: 259-264.

Thom, E.R.; Clark, D.A.; Waugh, C.D. 1999. Endophyte and dairy production in New Zealand: experience at the Dairying Research Corporation. Ryegrass endophyte: an essential New Zealand Symbiosis. Grassland Research and Practice Series No. 7: 3944.

Thompson, F.N.; Stuedemann, J.A. 1993. Pathophysiology of fescue toxicosis. Agriculture, Ecosystems \& Environment 44: 263-281.

Thompson, R.W.; Fribourg, H.A.; Waller, J.C.; Sanders, W.L.; Reynolds, J.H.; Phillips, J.M.; Schmidt, S.P.; Crawford, R.J., Jr.; Allen, V.G.; Faulkner, D.B.; Hoveland, C.S.; Fontenot, J.P.; Carlisle, R.J.; Hunter, P.P. 1993. Combined analysis of tall fescue steer grazing studies in the Eastern United States. Journal of Animal Science 71: 1940-1946.

Valentine, S.C.; Bartsch, B.D.; Carroll, P.D. 1993. Production and composition of milk by dairy cattle grazing high and low endophyte cultivars of perennial ryegrass. pp. 138-141. In: Proceedings of the Second International Symposium on Acremonium/Grass Interactions.

Watson, R.H.; Keogh, R.G.; McDonald, M.F. 1999. Ewe reproductive performance and growth rate of suckling-lambs on endophyte-infected perennial ryegrass pasture. Ryegrass endophyte: an essential New Zealand Symbiosis. Grassland Research and Practice Series No. 7: 19-26.

Yates, S.G.; Plattner, R.D.; Garner, G.B. 1985. Detection of ergopeptine alkaloids in endophyte infected, toxic Ky-31 tall fescue by mass spectrometry/mass spectrometry. Journal of Agricultural and Food Chemistry 33: 719-722. 